\author{
ACTA MYCOLOGICA \\ Vol. 47 (1): 91-96 \\ 2012
}

\title{
Immunomodulating and anticancer properties of fungi
}

\author{
KAZIMIERZ KOPCZYŃSKI
}

\begin{abstract}
Jan Kochanowski University in Kielce, Branch in Piotrków Trybunalski Słowackiego 114/118, PL-97-300 Piotrków Tryb., inp@unipt.pl
\end{abstract}

Kopczyński K.: Immunomodulating and anticancer properties of fungi. Acta Mycol. 47 (1): 91-96, 2012.

Fungi contain a number of biologically active substances whose importance for human health has been confirmed in several studies. In particular, $\beta$-glucans, selenium, vitamin $D, C$ and $\mathrm{E}$ should be mentioned. These substances play an important role in shaping the immune system and prevent cancer. $\beta$-Glucans reduce the risk of cardiovascular disease and lower the cholesterol level.

Key words: selenium, $\beta$-glucans, vitamins, immunity, cancer

\section{INTRODUCTION}

This article is a review and an attempt to synthesize the results of the studies on immunomodulating and anticancer properties of mushrooms. Usually, scientific reports present only individual components being of importance for the human health contained in mushrooms (Beuth, Drebing 2006; Marley 2009). However, such substances as $\beta$-glucans, selenium and some vitamins and minerals occur in mushrooms simultaneously, making the effect of stimulation of the immune system and anticancer action stronger. Worth mentioning is the fact that glucans can be present in a wide variety of configurations, that have different biological activity. According to some researchers, the use of a mixture of different species of fungi with a wide variety of glucans can further enhance their immune effects.

The study presents the health effects of substances contained in mushrooms, such as selenium, $\beta$-glucans, some vitamins and minerals. The main purpose was to expose the fact that these components appear jointly in fungi and their immunomodulating and anticancer activity has been confirmed by many studies. In the light of these studies, a widespread belief that mushroom's values are only a taste and aromatic qualities seems to be a myth. The therapeutic value of many edible mushrooms, examples of which are given in this paper, has been thoroughly confirmed in the recent 
years, as indicated by the cited literature, including scientific reports in the field of oncology and immunology. This paper demonstrates practical importance of fungi in shaping the immune system and in preventing and fighting cancer.

\section{ACTIVE COMPOUNDS AND THEIR EFFECTS}

Selenium is one of indispensable microelements for proper functioning of enzymatic systems. The principal function of selenium is creation of glutathione peroxidase, a powerful antioxidant enzyme. It protects red blood cells and cellular membranes from harmful effect of (free) radicals. It is also important for proper functioning of immunity system and thyroid gland. Numerous research confirm that selenium decreases the risk of occurrence of all kinds of cancer, in particular liver, prostate, colon and lungs cancers (Hasik 2000; Beuth, Drebing 2006; Juchimiuk et al. 2010).

When compared to the control group, significantly lower level of selenium in the serum was found among the patients with early and advanced stage of stomach cancer (Juchimiuk et al. 2010). Other data confirm that fewer cases of bronchial cancer were found in the group of patients with high level of selenium in serum (Hasik 2000). Also the risk of prostate cancer is four to five times higher in the group of patients with low level of this element in serum (Brooks et al. 2001; Rostock, Saller 2008).

Selenium can mitigate effects of chemotherapy and radiotherapy, prevents the phenomenon of metastasis and protects against the ultraviolet radiation (Beuth, Drebing 2006). Selenium present in the structure of glutathione peroxidase takes part in regeneration of vitamin E in biological systems (Kostogrys 2007). Vitamin E together with $\beta$-carotene and selenium are among the most important antioxidants. It is belived that vitamin $\mathrm{E}$ is effective in high oxygene pressure conditions which can be found in lungs (Szponar, Respondek 2000).

According to the literature, therapeutic substances that have significant anticancer effect contained in vegetables and fruit are described as blocking agents or supperssing agents depending on the strength and phase of their action. Similarly, selenium is considered as a suppressing agent - acting through enzymatic breakdown of carcinogens (Hasik 2000).

The level of selenium in fungi varies within the limits from 0.31 to $19.86 \mathrm{mg} /$ $\mathrm{kg} \mathrm{d.m.} \mathrm{Its} \mathrm{content} \mathrm{depends} \mathrm{not} \mathrm{only} \mathrm{on} \mathrm{the} \mathrm{species} \mathrm{but} \mathrm{also} \mathrm{on} \mathrm{the} \mathrm{location} \mathrm{and}$ collecting season. It may also depend on the method of measurement of this element. Results obtained with inductively-coupled plasma atomic emission spectroscopy (ICP-AES) may differ from those obtained by other techniques. However, as noted by Falandysz (2011) selenium is one of the chemical elements always present in mushrooms.

The highest content of selenium was found in the following species of edible fungi: Boletus edulis Bull, Xerocomus badius (Fr.) J.-E. Gilbert, Stropharia rugosoannulata Farl. ex Murril, Leccinum aurantiacum (Bull.) Grey (Lasota, Kalinowski and Florczak 1994). 
及-Glucan is the polysaccharide extracted from the cellular membranes of yeasts (Saccharomyces cerevisiae Meyen ex E. C. Hansen) a patented method of "gentle" extraction allows to preserve intact the bindings $1,3 / 1,6 \mathrm{D}$, which activate macrophages. $\beta$-glucans are strong stimulants of macrophages, increase immunity against different bacterial, viral, fungal and parasitic infections, delay ageing processes, slow down the growth of tumors, act as strengtheners of proliferation phase of wounds healing, protect against negative effects of standard cancer treatment, improve its effectiveness, prevent the phenomenon of metastasis, decrease the risk of circulatory system diseases, lower the cholesterol level and influence the antihyperglicemic effect (Ber, Gazella 2002; Marley 2009; Strach 2011).

Glucans are present in incredibly wide range of configurations that influence their biological activity. The ones with branches $\beta-1,3$ and $\beta-1,6$ proved to be the most active in immunity stimulation. Overall growth of branching in size and complexity is accompanied by increase of biological activity (Ohno 2005). According to some researchers, using a mixture of different species of fungi with a wide variety of glucans may cause an increased immune activity (Marley 2009).

Glucans are not readily available without prior boiling of fungi in order to break the structure of their cell walls. Cooking of the mushrooms enables digesting and releases the polysaccharides, which would otherwise remain in the indigestible cell structures (Marley 2009).

$\beta$-Glucans and other polysaccharides with non-specific immunomodulational properties were found in such species of fungi as: Pleurotus ostreatus (Jacq.) P. Kumm., Tricholoma caligatum (Viv.) Ricken, Auricularia auricula-judae (Bull.) Quél., Lepista flaccida (Sowerby) Pat., Sparassis crispa (Wulf.) Fr., Lyophyllum decastes (Fr.) Singer (Żurowska 2010). All these species are edible (Lepista flaccida, a very spicy mushroom, can be consumed only in small amounts in addition to spicy roast).

Research conducted in National Cancer Institute of Tokyo on the species Flammulina velutipes (Curtis) Singer, demonstrated that it also contains polysaccharides and antioxidants: vitamin $\mathrm{C}$ and $\mathrm{E}$ (Babal 2011). This species is especially valuable, since it occurs in winter, when no other edible mushrooms do. Some authors indicate a large content of B-glucans in mushrooms (Agaricus) and in shiitake Lentinus edodes (Berk.) Singer (Ley 2008; Babal 2011). However, there are reports on cancerogenous and mutagenous effects of these fungi as well (Sadowska et al. 2004; Škubla 2005). Experiments on animals indicated cancerogenous effect of agarityn found in numerous species of the genus Agaricus.

Derivatives of hydrazine are also carcinogens, resulting in colon tumors and other cancers in experimental animals. Hydrazine derivatives were found in some species of the genus Agaricus, and shiitake mushrooms (Sadowska et al. 2004). These species should be evaluated with caution. Škubla (2005) rightly says that no mushroom can be recommended for consumption.

In the recent years, studies on the diversity of polysaccharides and their biological activity have been carried out at a fairly large scale. Fan et al. (2006) indicate that more than 650 species of fungi representing more than 180 genera are known for containing polysaccharides that stimulate the immune system and act as anti-cancer agents. 
Vitamins and minerals. In addition to selenium and $\beta$-glucans, fungi contain other substances valuable for human health. Vitamin D should be indicated here in particular. A component of the cell walls of fungi - ergosterol - is converted into vitamin $\mathrm{D}_{2}$ in the presence of sunlight or other ultraviolet light source (Marley 2009; Babal 2011). This vitamin has an essential role in prevention of cancer, as it results in increased phagocytosis (absorption and destruction of cancer cells) and facilitating other immunomodulatory functions. It is also responsible for the absorption of calcium and phosphorus, which enables normal growth of bones and prevents osteoporosis (Marley 2009). In laboratory studies, it has been found that vitamin D slows the growth of cancer cells and its administration in animal studies resulted in the decrease of the incidence of breast cancer by half (Carper1995).

Tomasik (2008) lists the mushrooms as one of the four main sources of vitamin D in food. Gertig (2007) indicates that significant amounts of vitamin D are contained in fish and mushrooms. For example, the edible parts of halibut contain about $4 \mu \mathrm{g}$, while porcini mushrooms (Boletus) about $7 \mu \mathrm{g}$ per $100 \mathrm{~g}$ of the product. In the recent exciting discoveries it has been found that mushrooms exposed to ultraviolet rays, either before or after the collection, quickly convert ergosterol to vitamin $\mathrm{D}_{2}$ in astonishing quantities. Cases where vitamin D levels have increased hundredfold during the drying of mushrooms in the sun in comparison with the mushrooms dried in the dark are cited. This increase was so significant that the possibility of an overdose of vitamin D in people who had eaten mushrooms dried in the sun was considered, but toxicity of vitamin D assimilated from fungi was not recorded (Marley 2009).

Another important influence of vitamin D is worth mentioning. In the course of cancer, formation of microvessels within the tumor (angiogenesis) plays an important role. The progression of cancer may be limited by limiting the functions of proangiogenic factors. One of the factors blocking the formation of new blood vessels needed for tumor growth is adequate diet (Mraz et al. 2010). The use of this dietary vitamin D may be important, because vitamin D analogues are on the list of factors responsible for the inhibition of angiogenesis (Obrocka et al. 2002; Wcisło 2010).

The importance of minerals is also stressed. Providing large amounts of calcium from food significantly reduces the risk of developing colorectal cancer (Hasik 2000). As already mentioned, vitamin D is responsible for the absorption of calcium, so it is involved in the cancer prevention. Besides vitamin $\mathrm{D}$, mushrooms contain, among others, vitamin B, C, E and K (Marley 2009). Particular importance of vitamin C and $\mathrm{E}$ in cancer prevention is indicated i.a. by Hasik (2000) and Unger and Hildenbrand (2008). Hasik (2000) states that nitrosoamines belong to the strongest carcinogens, while vitamin $\mathrm{C}$ has significant inhibitory effect on the formation of nitrosoamines (Ber, Gazella 2002).

\section{CONCLUSIONS}

For 25 years Klimuszko (1988) advocated the use of fungi in medicine and applied a delicate mushroom cure with good results in almost all cases for those whose organisms were ultimately exhausted due to various diseases. He concluded the 
beneficial effect of edible mushrooms from the fact that they are often found next to the highly poisonous species, thus, for the balance of biological effects that has to be sustained in Nature, they must have significant positive effects, even if imperceptible, but equal in strength to the poison. In the light of the above-described immunomodulatory and anti-cancerogenous properties of fungi, therapeutic effects of Klimuszko's fungal diets appear to be understandable.

While consuming mushrooms and their immunomodulatory and anti-cancer components, the organism becomes more resistant, thus protected from disease; even if the disease develops, fungi help to return to a good health.

Acknowledgements. I would like to express my thanks to Prof. Maria Ławrynowicz and to the participants of the mycological conference "Traditional use and protection of fungi in Poland: a contribution to the European cultural heritage”, Łódź, 3-5.11.2011. for encouragement to publish this paper.

\section{REFERENCES}

Andres R., Carter H. B. 2001. Plasma selenium level before diagnosis and the risk of prostate cancer development. J. Urol. 166: 2034-2038.

Babal K. 2011. Mushrooms for health and longevity. Books alive, Summertown.

Ber L., Gazella K. A. 2002. Uaktywnij swój system immunologiczny. IMMUDYNE, Houston.

Beuth J., Drebling V. 2006. Selen gegen Krebs. Medizinverlage TRIAS, Stuttgart.

Brooks J. D., Metter E. J., Chan D. W., Sokoll L. J., Landis P., Nelson W. G., Muller D., Anders R., Carter H.B. 2001. Plasma selenium level befor diagnosis and the risk of prostate cancer development. J. Urol. 166: 2034-2038.

Carper J. 1995. Żywność twój cudowny lek. Hannah Publishing Ltg, London.

Falandysz J. 2011. A review of studies on selenium in higher mushrooms. (In:) M. Lawrynowicz, M. Ruszkiewicz-Michalska, I. Kałucka (eds). Polskie tradycje użytkowania grzybów oraz ich ochrony wkładem do europejskiego dziedzictwa kultury (Traditional use and protection of fungi in Poland: a contribution to the European cultural heritage): 40. Wydawnictwo UŁ, Łódź.

Fan L., Pan H., Soccol A. T., Pandey A., Soccol C. R. 2006. Advances in mushroom research in the last decade. Food Technology and Biotechnology 44 (3): 303-311.

Gertig H., Przysławski J. 2007. Bromatologia. Wydawnictwo Lekarskie PZWL, Warszawa.

Hasik J. 2000. Żywienie a nowotwory. (In:) J. Hasik, J. Gawęcki (eds). Żywienie człowieka zdrowego i chorego. PWN, Warszawa: 247-253.

Juchimiuk M., Kamocki Z., Orywal K., Kędra B., Kukliński A., Korczewska-Niegierysz E., Zaręba K., Szmitowski M. 2010. Ocena selenu w surowicy u chorych z zaawansowanym i wczesnym rakiem żołądka. Postępy Żywienia Klinicznego 5: 13.

Klimuszko A. C. 1988. Wróćmy do ziół. Instytut Prasy i Wydawnictw NOVUM, Warszawa.

Kostogrys R. 2007. Wzbogacanie żywności pochodzenia zwierzęcego w związki przeciwutleniające. (In:) W. Grajek (ed.). Przeciwutleniacze w żywności. Wydawnictwo Naukowo-Techniczne, Warszawa:223-228.

Lasota W., Kalinowski R., Florczak J. 1994. Poziom selenu w niektórych gatunkach grzybów. (In:) A. Kabata-Pendias, B. Szetke (eds). Arsen i selen w środowisku. Problemy ekologiczne i metodyczne. PAN, Warszawa: 76-81.

Ley B. M. 2008. Medicinal mushrooms for immune enhancement: Agaricus blazei Murill. BL Publications, Hanover.

Marley G. A. 2009. Mushrooms for health. Down East, Rockport.

Mraz M., Woźniewski M., Kacprzak G., Kübler A. 2010. Postępowanie wspomagające. (In:) J. Kołodziej, M. Marciniak (eds). Rak płuca. Termedia Wydawnictwa Medyczne, Poznań: 207-231.

Obrocka B., Wcisło G., Nurzyński P., Korniluk J., Pawlak W. Z., Duchnowska R., Szarlej-Wcisło K. 2002. Celowana terapia antyangiogenna raka nerki. Współcz. Onkol. 4: 242-248.

Ohno N. 2005. Structural diversity and physilogical function of beta-glucans. International Journal of Medicinal Mushrooms 7 (1/2): 167-173. 
Rostock M., Saller R. 2008. Niekonwencjonalne leki w terapii nowotworów. (In:) C. Unger, J. Weis (eds). Onkologia. Wydawnictwo MedPharm Polska, Wrocław: 94-181.

Sadowska A., Obidoska G., Ruszkowska J., Rumowska M., Łata B. 2004. Rakotwórcze i trujące substancje roślinne. Wydawnictwo SGGW, Warszawa.

Škubla P. 2005. Atlas grzybów. Vydavatiel'stvo Slovart - Wydawnictwo SOLIS, Bratislava-Warszawa.

Strach M. 2011. Układ odpornościowy u ludzi starszych. Infekcje i ich profilaktyka. Materiały dydaktyczne Medycznego Centrum Kształcenia Podyplomowego Uniwersytetu Jagiellońskiego. UJ, Kraków.

Szponar L., Respondek W. 2000. Choroby pierwotne na tle niedoborów żywieniowych. (In:) J. Hasik, J. Gawęcki (eds). Żywienie człowieka zdrowego i chorego. PWN, Warszawa: 95-110.

Tomasik P. 2008. Witamina D. (In:) P. P. Lewicki (ed.). Leksykon nauki o żywności i żywieniu człowieka oraz polsko-angielski słownik terminów: 483. Wydawnictwo SGGW, Warszawa.

Unger C., Hildenbrand B. 2008. System immunologiczny i ochrona immunologiczna przed nowotworem. (In:) C. Unger, J. Weis (eds). Onkologia. Wydawnictwo MedPharm Polska, Wrocław: 76-93.

Wcisło G. 2010. Związki chemiczne w trakcie badań jako potencjalne leki i eksperymentalne sposoby terapii raka nerki. (In:) C. Szczylik, G. Wcisło (eds). Rak nerki. Termedia Wydawnictwo Medyczne, Poznań: 297-322.

Żurowska K. 2010. Grzyby, rośliny, beta-glukany - tajemnica poprawy odporności. Medycyna Estetyczna i Anti-Aging 1: 40-42.

\title{
Immunomodulacyjne i przeciwnowotworowe właściwości grzybów
}

\begin{abstract}
Streszczenie
Niniejszy artykuł jest próbą syntezy wyników badań nad immunomodulacyjnymi i przeciwnowotworowymi właściwościami grzybów. Dotychczas prezentowano zwykle naukowe doniesienia o którymś ze zdrowotnych składników zawartych w grzybach. Dla kształtowania odporności organizmu i zapobiegania nowotworom duże znaczenie mają $\beta$-glukany i selen, a także witamina D, C i E. Substancje te występują równocześnie w grzybach, które wskutek tego uzyskują szczególną wartość zdrowotną. Zdaniem niektórych badaczy, stosowanie mieszanki różnych gatunków grzybów z szeroką różnorodnością glukanów może spowodować zwiększone działanie odpornościowe. Glukany bowiem występują w niewiarygodnie różnorodnych konfiguracjach, odzwierciedlających zakres ich biologicznego działania. W ostatnich fascynujących odkryciach stwierdzono także, iż grzyby suszone na słońcu (wystawione na działanie promieni ultrafioletowych) szybko przetwarzają ergosterol - składnik ścian komórkowych grzybów w witaminę $\mathrm{D}_{2}$ w zdumiewającej ilości. Mitem okazuje się - w świetle współczesnych badań - rozpowszechnione mniemanie o jedynie smakowych i aromatycznych walorach grzybów.
\end{abstract}

